The Catholic University of America, Columbus School of Law

CUA Law Scholarship Repository

Scholarly Articles and Other Contributions

Faculty Scholarship

2000

Religious Liberty and the Politics of Judicial Review

Robert A. Destro

The Catholic University of America, Columbus School of Law

Follow this and additional works at: https://scholarship.law.edu/scholar

Part of the Constitutional Law Commons, First Amendment Commons, and the Religion Law Commons

Recommended Citation

Robert A. Destro, Religious Liberty and the Politics of Judicial Review, 7 EUR. J. CHURCH \& ST. RES. 409 (2000).

This Article is brought to you for free and open access by the Faculty Scholarship at CUA Law Scholarship Repository. It has been accepted for inclusion in Scholarly Articles and Other Contributions by an authorized administrator of CUA Law Scholarship Repository. For more information, please contact edinger@law.edu. 


\title{
RELIGIOUS LIBERTY AND THE POLITICS OF JUDICIAL REVIEW.
}

\author{
A PRE-ELECTION REVIEW OF THE CASES DECIDED BY \\ THE UNITED STATES SUPREME COURT DURING ITS \\ 1999-2000 TERM
}

ROBERT A. DESTRO

Viewed from virtually any perspective, the 1999 October Term of the United States Supreme Court was one of the most significant in recent memory. The Court considered at least three cases where religious liberty is one of the central issues, and another four or five where the issue of religious liberty is one of the primary interests affected.

The issues were difficult as well. Among the thorny issues discussed are: prayer in government-sponsored school programs ${ }^{1}$, the constitutionality of state-provided computers in religiously affiliated schools ${ }^{2}$, the right of the Boy Scouts of America to refuse a scoutmaster position to an openly homosexual $\mathrm{man}^{3}$, the right of anti-abortion demonstrators to protest outside abortion clinics ${ }^{4}$, the power of State governments to prohibit a form of late-term abortion that involves delivery of all but the child's head and the vacuum suctioning of its brain ${ }^{5}$, the power of a State university to compel its students to pay for political and ideological activities with which they disagree ${ }^{6}$, the power of states to regulate

\footnotetext{
1 Santa Fe Independent School District v. Doe, 530 U.S. 290, 120 S.Ct. 2266 (2000).

2 Mitchell v. Helms, - U.S. -, 120 S.Ct. 2530 (2000).

3 Boy Scouts of America v. Dale, 530 U.S. 640, 120 S.Ct. 2446 (2000).

4 Hill v. Colorado, 530 U.S. 703, 120 S.Ct. 2480 (2000).

5 Stenberg v. Carhart, 530 U.S. 914, 120 S.Ct. 2597 (2000).

6 Board of Regents of the University of Wisconsin System v. Southworth, 529 U.S. 217, 120 S.Ct. 1346 (2000).
} 
political and commercial speech and association for political purposes 7 and paternal grandparents' rights to visit with their grandchildren ${ }^{8}$.

Each of these issues is difficult, legally and politically, but that is not what makes the cases decided during the past term so interesting and involves a difficult reaches the United States Supreme Court unless it icy. The cases decided during the important issue of public polbecause the number of cases the 1999 October Term are important provides legal schors kands of issues rare opportunity to probe deeply ints, and political advocacy groups a see clearly how the composition of the thinking of the Court, and to

ical interests that are important to them.

Insights into how the composition of the Court affects policy are always interesting, but never so important as in a Presidential election year. The President of the United States has the power, with the advice and consent of the Senate, to appoint Justices to the Supreme Court, but most Presidents are lucky if they get the opportunity to make even one appointment during their tenure in office. Federal judicial appointments in the United States are for life during good behaviour, and it is reaches a ripe old age.

At present, the

have, or have had, serious health problems is nearly 70, and several W. Bush know that the next President will liketh Al Gore and George to appoint at least two, if not more Justices th have the opportunity doing change its composition and direction to the Court, and in so for the next generation.

This article, therefore, has two parts. The first is a brief summary of the three cases decided during the term ending in June 2000 that are likely to be of interest to the readers of this journal, and the second is a brief analysis of their political significance.

7 California Democratic Party v. Jones, 530 U.S. 567, 120 S.Ct. 2402 (2000) (right 529 U.S. 803, 120 S. explicit cable television programming to "scramble" children); Los Angeles Police Departo "scramble" the signal so as to prevent access by Corporation, 528 U.S. 32, 120 S.Ct. 483 (2000) v. United Reporting Publishing records).

${ }^{8}$ Troxel v. Granville, 530 U.S. 57, 120 S.Ct. 2054 (2000). 


\section{REVIEWING THE CASE LAW: RELIGIOUS LIBERTY IN THE OCTOBER TERM, 1999}

\section{A. Theoretical Background}

Before embarking on a review of the cases decided during the 19992000 Term, it will be useful to recount the relevant constitutional and structural concerns that provide the context in which these cases were decided.

The United States is a federal republic. Even though the federal government has enormous power over the national economy, trade, national defence and infrastructure, and a wide variety of commercial and tax issues, much of what might be termed "social policy" lies within the sovereign powers reserved to the States ${ }^{9}$. If the federal government is to be involved in these issues at all, the United States Supreme Court must find a federal interest that either Congress or the Court is empowered by the Constitution to protect.

When the issue is religious liberty, the claim of federal jurisdiction to make rules binding on the States is based on sections one and five of the fourteenth amendment. They provide:

Section 1. All persons born or naturalised in the United States, and subject to the jurisdiction thereof, are citizens of the United States and of the State wherein they reside. No State shall make or enforce any law which shall abridge the privileges or immunities of citizens of the United States; nor shall any State deprive any person of life, liberty, or property, without due process of law; nor deny to any person within its jurisdiction the equal protection of the laws.

Section 5. The Congress shall have power to enforce, by appropriate legislation, the provisions of this article ${ }^{10}$.

The first amendment provides that:

Congress shall make no law respecting an establishment of religion, or prohibiting the free exercise thereof; or abridging the freedom of speech, or of the press; or the right of the people peaceably to assemble, and to petition the Government for a redress of grievances.

Because the first amendment, by its terms, applies only to the federal government's actions ("Congress shall make no law..."), there is no clear warrant for federal intervention into State-level matters dealing with religious freedom. Since the 1940s, however, the United States

9 U.S. Const. arts. I, IV (1787); amends. IX, X (1791).

10 U.S. Const., Amend. XIV $\$ \$ 1,5$ (1868). See City of Boerne v. Flores, 521 U.S. 507, 517-521, 117 S.Ct. 2157 (1995). 
Supreme Court has held that the Due Process Clause of the fourteenth amendment ${ }^{11}$ "incorporates" (or simply, "includes") liberty interests that a majority of the Court is willing to characterise as "fundamental". The Free Exercise Clause of the First Amendment was applied to the States in $1940^{12}$, and the Establishment Clause was held to apply to the States in $1947^{13}$, but the Court has not spent much time elaborating either the source of federal power to define the permissible scope of the religious liberty guarantee, or its own view of the relationships between and among the guarantees contained in the first and fourteenth amendments ${ }^{14}$. It is only when the case law seems to indicate a head-on collision between one or more of these guarantees, or between and among the sovereign authorities empowered to make rules affecting religious liberty, freedom of speech and press, and the rights of free association and petition for redress of grievances, that we get a good indication of the Courts views on these subjects. The cases decided this term have every one of these elements.

\section{B. Summarising the Cases}

\section{Mitchell v. Helms, 120 S.Ct. 2530 (2000)}

In Mitchell $v$. Helms, a group of Louisiana taxpayers challenged the constitutionality of a federal program established by Title II of the federal Elementary and Secondary Education Act ${ }^{15}$, which permits a State to provide "instructional and educational materials, including library services and materials (including media materials), assessments, reference materials, computer software and hardware for instructional use,

11 The Due Process Clause of the fourteenth amendment provides, in relevant part: "...nor shall any State deprive any person of life, liberty, or property, without due process of law...".

12 Cantwell v. Connecticut, 310 U.S. 296 (1940).

13 Everson v. Board of Education, 330 U.S. 1 (1947).

14 See generally, DESTRO, R.A., "By What Right?' The Sources and Limits of Federal Court and Congressional Jurisdiction Over Matters 'Touching Religion"', Indiana Law Review, 29(1996), 1-103; Destro, R.A., "The Structural Components of Religious Liberty", in Symposium in Honor of Judge John Noonan, J. Law \& Religion, 11(1995), 355409; DeSTRO, R.A., "Equal Treatment: Implications for Nonprofit Organizations", in MONSMA, S.V. and SOPER, Chr., Equal Treatment of Religion in a Pluralistic Society, Grand Rappids, Eerdmans, 1998, 101-135; DESTRO, R.A., "Citizenship and Community: Legacy and Challenge", in Boxx, T.W. and QUINLIVAN, G.M. (ed.), Law and the Free Society, Latrobe, Center for Economic and Policy Education, 1998, 23-44.

15 Chapter 2 was codified by the Improving America's Schools Act of 1994, Pub.L. $103-382,108$ Stat. 3707. Prior to 1994, Chapter 2 was codified at 20 U.S.C. $\$ \$ 2911-$ 2976 (1988 ed.) 
and other curricular materials"16 to school children. Under the Act, States may provide such aid to both public and private schools, including those that are church-related. The law requires, however, that the "services, materials, and equipment" provided to private schools must be "secular, neutral, and non-ideological ${ }^{17 "}$. The Court upheld the program challenged in Mitchell $v$. Helms by a vote of 6-3, but the plurality divided (4-2) over the appropriate rules to be applied in such cases.

Four Justices (Thomas, Scalia, Rehnquist, and Kennedy) rejected the two main arguments made by the taxpayers challenging the statute. In the view of these Justices, the key inquiries in a case involving allegations of impermissible financial support of religious activity are equality, neutrality, and private choice:

For if numerous private choices, rather than the single choice of a government, determine the distribution of aid pursuant to neutral eligibility criteria, then a government cannot, or at least cannot easily, grant special favours that might lead to a religious establishment. Private choice also helps guarantee neutrality by mitigating the preference for pre-existing recipients that is arguably inherent in any governmental aid program, $\ldots$, and that could lead to a program inadvertently favouring one religion or favouring religious private schools in general over non-religious ones $^{18}$.

Justices O'Connor and Breyer agreed that the aid program should be upheld, but rejected the breadth and scope of their colleagues' reasoning:

I write separately because, in my view, the plurality announces a rule of unprecedented breadth for the evaluation of Establishment Clause challenges to government school-aid programs. Reduced to its essentials, the plurality's rule states that government aid to religious schools does not have the effect of advancing religion so long as the aid is offered on a neutral basis and the aid is secular in content. The plurality also rejects the distinction between direct and indirect aid, and holds that the actual diversion of secular aid by a religious school to the advancement of its religious mission is permissible. Although the expansive scope of the plurality's rule is troubling, two specific aspects of the opinion compel me to write separately. First, the plurality's treatment of neutrality comes close to assigning that factor singular importance in the future adjudication of Establishment Clause challenges to government school-aid programs. Second, the plurality's approval of actual diversion of government aid to religious indoctrination is in tension with our precedents and, in any event, unnecessary to decide the instant case ${ }^{19}$.

1620 U.S.C. $\$ 7351(\mathrm{~b})(2)$

1720 U.S.C. $\$ 7372(\mathrm{a})(1)$.

${ }_{18}$ Mitchell v. Helms, 120 S.Ct. at 2541-42.

19 Id., 120 S.Ct. at 2556 (O'Connor \& Breyer, JJ. concurring). 
The dissenters (Justices Souter, Stevens and Ginsburg) conceded that the task of policing the boundary between religion and government is a difficult one, and that the Court's reasoning has often been unclear:

Because the First Amendment also bars any prohibition of individual free exercise of religion, and because religious organisations cannot be isolated from the basic government functions that create the civil environment, it is as much necessary as it is difficult to draw lines between forbidden aid and lawful benefit. For more than 50 years, this Court has been attempting to draw these lines. Owing to the variety of factual circumstances in which the lines must be drawn, not all of the points creating the boundary have enjoyed self-evidence ${ }^{20}$.

Nevertheless, they argued, "a few fundamental generalisations are nonetheless possible".

There may be no aid supporting a sectarian school's religious exercise or the discharge of its religious mission, while aid of a secular character with no discernible benefit to such a sectarian objective is allowable. Because the religious and secular spheres largely overlap in the life of many such schools, the Court has tried to identify some facts likely to reveal the relative religious or secular intent or effect of the government benefits in particular circumstances. We have asked whether the government is acting neutrally in distributing its money, and about the form of the aid itself, its path from government to religious institution, its divertibility to religious nurture, its potential for reducing traditional expenditures of religious institutions, and its relative importance to the recipient, among other things ${ }^{21}$.

The problem, in the dissenters' view, was conceptual.

It is not just that a majority today mistakes the significance of facts that have led to conclusions of unconstitutionality in earlier cases, though I believe the Court commits error in failing to recognise the divertibility of funds to the service of religious objectives. What is more important is the view revealed in the plurality opinion, which espouses a new conception of neutrality as a practically sufficient test of constitutionality that would, if adopted by the Court, eliminate enquiry into a law's effects. The plurality position breaks fundamentally with Establishment Clause principle, and with the methodology painstakingly worked out in support of $i^{22}$.

To an American scholar, policy analyst, or politician, Mitchell v. Helms is important because it is now very clear where the Court stands on the following questions.

20 Id., 120 S.Ct. at 2572-73 (Souter, Stevens \& Ginsburg, JJ., dissenting).

${ }^{21}$ Id. at 2573.

22 Id. 
THE UNITED STATES SUPREME COURT DURING ITS 1999-2000 TERM 415

Question Yes "Maybe" No

$\begin{aligned} & \text { May the State provide the same forms of educational and social } \\ & \text { assistance to children enrolled in church-related schools as it pro- } \\ & \text { vides to children in State-run public schools? }\end{aligned}$
$\begin{aligned} & \text { Must the aid be distributed on an equal basis to children enrolled in } \\ & \text { public and non-public schools? }\end{aligned}$
$\begin{aligned} & \text { Is the government's intent to favour or disfavour religious or non- } \\ & \text { religious choices a relevant factor in the constitutional analysis? }\end{aligned}$
$\begin{aligned} & \text { Is it relevant that the aid might have the effect of enhancing the reli- } \\ & \text { gious mission of the educational program provided by the church- } \\ & \text { related school? }\end{aligned}$
$\begin{aligned} & \text { Does the religious character of church-related schools create a } \\ & \text { unique set of risks that State assistance will be diverted to further } \\ & \text { the religious or ideological purposes of the school, rather than the } \\ & \text { secular educational purposes of the State? }\end{aligned}$
$\begin{aligned} & \text { Does the risk of diversion require that the Court talke the character } \\ & \text { of the assistance into account before ruling on its constitutionality? } \\ & \text { (i.e. Different rules may apply to different forms of aid, such as cash } \\ & \text { support payable to the school vs. cash support payable to parents, } \\ & \text { provision of teachers, durable equipment, software, books, etc.) }\end{aligned}$
$\begin{aligned} & \text { Does risk of diversion alone mandate invalidation of the aid pro- } \\ & \text { gram? }\end{aligned}$
$\begin{aligned} & \text { Does proof that some diversion has actually taken place mandate } \\ & \text { invalidation of the program? }\end{aligned}$

Information of this type enables the political branches to predict the Court's response to incremental changes in specific areas of public policy, and gives litigants invaluable information on the content and structure of the type of case that must be presented if one is to get the vote of a specific Justice. The political value of such information is enormous. Part II of this paper discusses the relevance of this information in the presidential election scheduled for November 2, 2000.

2. Santa Fe Independent School District v. Doe, 120 S.Ct. 2266 (2000)

In Santa Fe Independent School District v. Doe the issue before the Court was the constitutionality of student-led prayers immediately before the start of home interscholastic football games. By a vote of 6-3, the Court invalidated the practice.

It is tempting to describe the Santa Fe case as just "another school prayer case". Although in many ways that is just what it was, there is a very sophisticated legal and cultural subtext to the opinions that is not 
and to deliver overtly Christian prayers over the public address system at home football games ${ }^{28}$.

Once the litigation began, the federal District Court entered a series of orders that had the cumulative effect of taking control over the Santa Fe Independent School District's policies. Among its first orders was a detailed set of instructions concerning the rules that would govern prayer at the upcoming graduation ceremonies:

$[T]$ he order provided that "non-denominational prayer" consisting of "an invocation and/or benediction" could be presented by a senior student or students selected by members of the graduating class. The text of the prayer was to be determined by the students, without scrutiny or pre-approval by school officials. References to particular religious figures "such as Mohammed, Jesus, Buddha, or the like" would be permitted "as long as the general thrust of the prayer is non-proselytising ${ }^{29 "}$.

Another part of the District Court's order prohibited school officials from endorsing or participating in the baccalaureate ceremony sponsored by the Santa Fe Ministerial Alliance, and ordered the District to establish policies to deal with

"manifest First Amendment infractions of teachers, counsellors [sic], or other District or school officials or personnel, such as ridiculing, berating or holding up for inappropriate scrutiny or examination the beliefs of any individual students. Similarly, the School District will establish or clarify existing procedures for excluding overt or covert sectarian and proselytising religious teaching, such as the use of blatantly denominational religious terms in spelling lessons, denominational religious songs and poems in English or choir classes, denominational religious stories and parables in grammar lessons and the like, while at the same time allowing for frank and open discussion of moral, religious, and societal views and beliefs, which are nondenominational and non-judgmental ${ }^{30 \prime}$.

From this record, it is fairly clear that the Santa Fe, Texas Independent School District was acting in a manner that was perfectly consistent with its local religious culture, but very much at odds with the legal culture embodied in the holdings of the United States Supreme Court since 1962. Not surprisingly, the community attempted to preserve as much of their local culture as possible under the circumstances. Hoping to take advantage of more recent Supreme Court rulings holding that

\footnotetext{
28 Santa Fe, 120 S.Ct. at 2272 (footnote omitted).

29 Santa Fe, 120 S.Ct. at 2272, quoting Joint Appendix at 32.

30 Santa Fe, 120 S.Ct. at 2272, quoting Joint Appendix at 34.
} 
voluntary, student-initiated prayer in schools was constitutionally permissible, the Santa Fe School Board adopted the following policy to govern the scope of permissible prayer.

The board has chosen to permit the graduating senior class, with the advice and counsel of the senior class principal or designee, to elect by secret ballot to choose whether an invocation and benediction shall be part of the graduation exercise. If so chosen the class shall elect by secret ballot, from a list of student volunteers, students to deliver non-sectarian, non-proselytising invocations and benedictions for the purpose of solemnising their graduation ceremonies ${ }^{31}$.

The same policy was to apply to invocations at all football games played in Santa Fe.

The case thus sets up several important questions:

1. May a public school board adopt a policy governing student invocations that is intended to permit students to pray during public school functions or while on public school property?

2. Does the nature of the public school setting (or "forum") determine the extent to which free speech and free exercise of religion will be tolerated?

3. Does the fact that students initiate the invocations and control their content require that the students' rights to free speech and free exercise of religion be taken into account?

4. At what point should the a court utilise "social facts" to determine that the clash of cultures is sufficiently serious that it should intervene?

5. If intervention is appropriate, what remedy should the federal courts impose? A federal regime designed to forbid religious speech on the school campus or during official activities, or something other approach that will protect dissenting minority students, while preserving the right of students belonging to the majority religion to speak or act in a manner consistent with their religious beliefs and interests?

The Court divided 6-3 both the outcome and reasoning in the case.

The first question -May a public school board adopt a policy governing student invocations that is intended to permit students to pray during public school functions or while on public school property? appears to have been answered in the affirmative. A school board may adopt such a policy, but a court will scrutinise its historical and political

31 Santa Fe, 120 S.Ct. at 2272, quoting 168 F.3d 806, 811 (5th Cir. 1999) (emphasis deleted). 
pedigree in an effort to determine the school authorities "intent." If its purpose is to encourage prayer as a part of school activities, or sets up a process for allocating the right to speak, the program is unconstitutional.

The second question -Does the nature of the forum created have an impact on the constitutional analysis?- was also answered in the affirmative. After Santa Fe, a school wishing to permit student-initiated, voluntary prayer must make certain that the forum in which the speech takes place in "open" to persons otherwise-eligible to participate without regard to the content or viewpoint of the words they actually use. The problem, of course, is that virtually all fora created in public schools are subject to content and attendance restrictions. Santa Fe thus puts school boards wanting to permit voluntary prayer into a difficult position. If they exercise their right to control the content of all student speech that takes place during official school functions, the students cannot claim the creation of an "open forum" for discussion of religious issues. If they cede that control, they lose control of the educational experience and shirk their duties as public school administrators.

The third question -Does control of the content of student-initiated speech violate the first amendment rights of the students?- has generally been answered in the negative. The Court remains sensitive to the need for teachers to control classrooms and other fora in which educational functions take place, and has upheld even content-based restrictions on student-initiated speech wherever those restrictions are deemed necessary to shaping the educational experience.

The fourth and fifth questions -concerning the use of "social facts" to determine the proper judicial response- are part and parcel of the same inquiry. The situation in Santa Fe, Texas is replicated in many towns and cities across the United States, and the increasingly diverse nature of American society ensures that there will be constant litigation. The tendency in such cases is to assume that the "secular" response is not only the "best" solution, but is the only constitutional rule that comports with the rights of dissenters under the Establishment Clause.

It should not be surprising that the Court was divided over the appropriate response to each of these questions. Perhaps most telling is the split over an issue that seems minor in the context of the case, but which looms large when the "social facts" of the controversy over religion in the public schools are taken into account.

In a discussion that seems a bit arcane, the Court debated whether or not a law or administrative rule could be invalidated as unconstitutional "on its face" before it was actually used "in practice." In Santa Fe, all the 
parties assumed that the policy permitting student-initiated prayer could be applied constitutionally, but the majority doubted that the community was culturally capable of permitting anyone other than a member of the majority religion to lead the invocations.

The District, nevertheless, asks us to pretend that we do not recognise what every Santa Fe High School student understands clearly that this policy is about prayer. The District further asks us to accept what is obviously untrue: that these messages are necessary to "solemnise" a football game and that this single-student, year-long position is essential to the protection of student speech. We refuse to turn a blind eye to the context in which this policy arose, and that context quells any doubt that this policy was implemented with the purpose of endorsing school prayer ${ }^{32}$.

The Court is well aware that there is significant cultural and political opposition to its pronouncements on the role of religion in public schools. That, in part, is its point. But the Court seems to ignore the irony of its position.

The Court's view is that that it is unconstitutional for a dominant political group to use its political power to control the religious culture of the public schools, and thereby send a message to adherents of minority faiths "that they are outsiders, not full members of the political community, and an accompanying message to adherents [of the majority faith] that they are insiders, favoured members of the political community 33 ". Opponents of the Court's position are quick to point out that the Court is also using its political power to favour a different faction's view of the "proper" religious culture of the public schools. To these opponents, including the parents and children in the political majority in Santa Fe, the Court's message is that they are now "outsiders" in their own community. They have lost the right to make rules controlling the religious environment of the public schools of their community and must now must seek, and receive, the blessing of a federal court before they can take actions that they believe are in the best interests of their children.

They are not happy about it. A recent "Christian Coalition" church bulletin insert contained an article written by Christian Coalition of Georgia Chairwoman, Sadie Fields, who wrote that the Supreme Court's decision in Santa $\mathrm{Fe}$ was "as classic an example of tyranny as this

32 See Santa Fe, 120 S.Ct. at 2283.

33 Santa Fe, 120 S.Ct. at 2279, quoting Lynch v. Donnelly, 465 U.S., 668, 688 (1984) (O'CONNOR, J., concurring). 
nation has ever experienced ${ }^{34 "}$. It has also been reported that there are signs of open defiance in public schools around the Southern United States, as school children and their parents demonstrate their disdain for the Supreme Court's ruling by leading prayers before high school football games ${ }^{35}$.

What both sides miss in these debates is that such feelings are inevitable when factions vie for control of one of the primary cultureforming institutions in the community. Political compromise becomes impossible because the winner-take-all nature of the Supreme Court's approach to religion-in-schools cases assures there will always be a dissatisfied losing faction. For both Court and much of the political community, the preferred option has been to accept the proposition that the State should have political control of the content of the educational programs in the public schools. This is so precisely because of their importance in the formation of the common culture.

In the nineteenth century, the response of the State courts was that Bible-reading was "non-sectarian." This rationale enabled them to reject complaints by dissenters that the practice was designed to convert their children to a different way of thinking. Today, the United States Supreme Court appears to have adopted a similar approach. It assumes that the secular culture of the public schools is religiously "neutral", even though its own case docket increasingly demonstrates that it can often be hostile to the interests of religious students ${ }^{36}$. Rather than fashion a remedy that seeks to accommodate both sets of interests, the Court has been only partially accommodating to the interests of families that reject the culture of the public schools (whatever it is). While it does require the States to permit parents and children to choosing an alternative education, the discussion in Mitchell v. Helms demonstrates that state attempts to cover more than a minimal part of the cost of alternative education programs would not likely survive a federal constitutional challenge.

The Court has yet to give much thought to the structural problem created by political control over the content and perspective of educational programs funded at State expense. Given the central position that

34 SAlZER, J., "Southern High Schools Invite God to Gridiron", The Washington Times, Monday, August 28, 2000, A1, col. 2, at A9, col. 5 .

35 Id.

36 See, e.g., Tangipahoa Parish Board of Education v. Freiler, -.- U.S. ---, 120 S.Ct. 2706 (2000) (Scalia and Thomas, JJ. and Rehnquist, C.J. dissenting from the denial of certiorari in a case involving a public school disclaimer on the significance of the teaching of the theory of evolution).

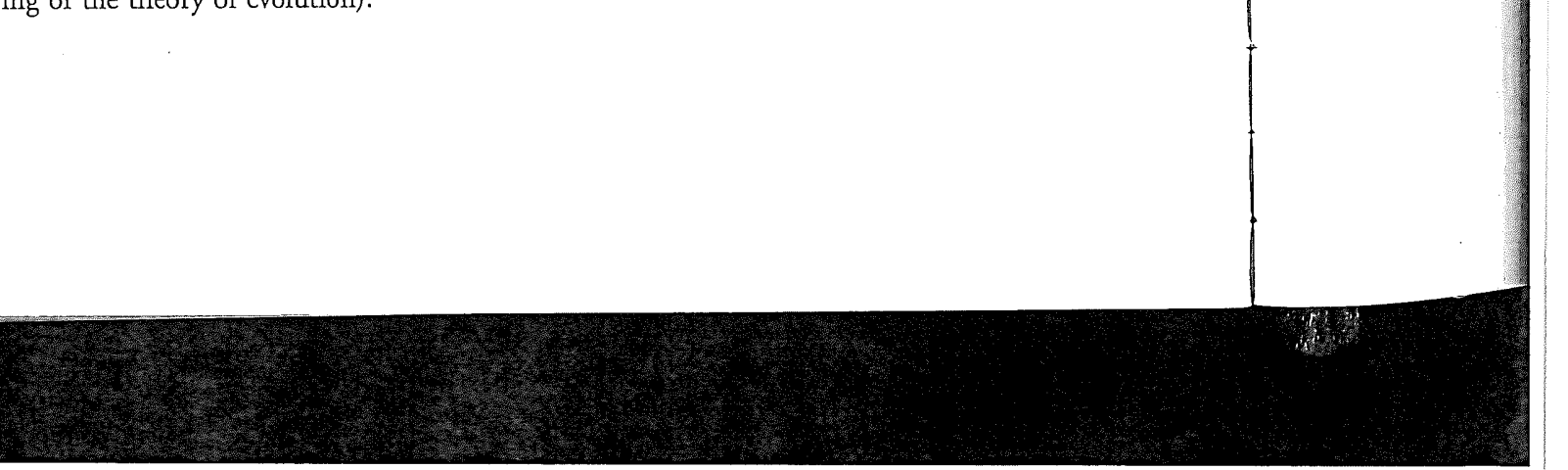


education and the role of religious organisations in providing social services will play in the 2000 presidential campaign, it seems certain that the new President, whoever he is, will give very careful consideration to this issue if a seat on the Supreme Court should become vacant.

\section{Boy Scouts of America v. Dale, 120 S.Ct. 2446 (2000)}

One of the most interesting and significant cases of the 1999 October term is Boy Scouts of America v. Dale. The primary issue in the case is whether a State may compel a private organisation, such as the Boy Scouts of America, to admit to its both membership and leadership an individual whose open homosexuality is alleged by the organisation to be antithetical to the message it is seeking to convey to the young boys and men who seek to join.

Although the case is not, by its terms, a religious freedom case, churches and religious institutions in the United States watched the case closely, and several participated in the Supreme Court litigation as amici curiae. Their reasons for participating were both practical and philosophical. Many churches and religious organisations sponsor Boy Scout activities, and a ruling in favour of $\mathrm{Mr}$. Dale would have forced them to reconsider their sponsorship. More importantly, the principle involved in Dale -that a voluntary organisation has the right to select its members and use the selection process to define the content of its association's point of view- is of critical importance to religious organisations fearful that the government will attempt to use human rights laws to assert control over messages and actions that it deems inconsistent with its views on social morality.

The plaintiff in the case was James Dale. Mr. Dale had been a Boy Scout throughout his childhood, and had advanced to the rank of Eagle Scout, one of the highest honours conferred by the Boy Scouts of America. After leaving high school, Mr. Dale applied for membership as an adult member of the Boy Scouts. The local Monmouth County Council of the Boy Scouts of America approved his application and appointed him to be scoutmaster of a local chapter.

The case arose when the Boy Scouts learned from a local newspaper that James Dale had openly declared his homosexual orientation. At the time of the interview, Mr. Dale was a student at Rutgers University and co-president of the Rutgers University Lesbian/Gay Alliance, and the interview focused on his views on the need of homosexual teenagers to have homosexual role modes. The article was accompanied by his picture, published over a caption identifying him as co-president of the Rutgers University Lesbian/Gay Alliance. 
The Boy Scouts revoked his adult membership. When asked why, they replied that the Boy Scouts "specifically forbid membership to homosexuals." Mr. Dale filed a complaint alleging that the Boy Scouts of America is a "place of public accommodation" under New Jersey law, and that the law specifically forbids discrimination on the basis of "affectional or sexual orientation ${ }^{37 "}$.

The New Jersey Supreme Court had ruled that the Boy Scouts of America is a "place of public accommodation" under New Jersey law, and thus subject to the non-discrimination law. In its view, a "public accommodation" is to be determined by reference to the following criteria:

1. Does the organisation engage in broad public solicitation of members?

2. Does the organisation maintain close relationships with the government or other public accommodations? Or

3. Is the organisation similar in character to the types of public accommodation enumerated in the anti-discrimination law or to other types of public accommodation identified by the $\operatorname{courts}^{38}$ ?

The New Jersey Supreme Court also rejected the Boy Scouts'statutory claim for an exemption on the grounds that it is an "educational facility operated or maintained by a bona fide religious or sectarian institution ${ }^{39 \%}$, and its claim that it was the delegate of parental authority to direct the education of the children entrusted to its care. Notwithstanding the Boy Scouts' argument that one of its key teachings is that homosexuality is incompatible with its view that a man must be "morally straight", the New Jersey Supreme Court held that the constitution does not protect the Boy Scouts from a charge of illegal discrimination:

We find that the [New Jersey] L[aw] A[gainst] D[iscrimination] does not violate Boy Scouts' freedom of expressive association because the statute does not have a significant impact on Boy Scout members' ability to associate with one another in pursuit of shared views. The organisation's ability to disseminate its message is not significantly affected by Dale's inclusion because: Boy Scout members do not associate for the purpose of disseminating the belief that homosexuality is immoral; Boy Scouts discourages its leaders from disseminating any views on sexual issues; and Boy Scouts includes sponsors and members who subscribe to different views in respect of homosexuality ${ }^{40}$.

37 N.J. Stat. Ann. $\$ \$ 10: 5-4$ and 10:5-5 (West Supp.2000).

38 Dale v. Boy Scouts of America, 160 N.J. 562, 589, 734 A.2d 1196, 1210 (1999).

39 N.J.S.A. $10: 5-51$.

40 Dale v. Boy Scouts of America, 160 N.J. at 612, 589, 734 A.2d at 1223. 
Perhaps more significantly, the New Jersey court also held that prohibition of discrimination on the basis of sexual orientation is a "compelling State interest" that may outweigh the religious, associational, and expression rights of organisations it deems to be "places of public accommodation."

By a vote of 5-4, the United States Supreme Court disagreed. Writing for the majority, Chief Justice William H. Rehnquist wrote:

The forced inclusion of an unwanted person in a group infringes the group's freedom of expressive association if the presence of that person affects in a significant way the group's ability to advocate public or private viewpoints. $\cdots$

We must [therefore] determine whether Dale's presence as an assistant scoutmaster would significantly burden the Boy Scouts' desire to not "promote homosexual conduct as a legitimate form of behaviour." ... As we give deference to an association's assertions regarding the nature of its expression, we must also give deference to an association's view of what would impair its expression. ... That is not to say that an expressive association can erect a shield against anti-discrimination laws simply by asserting that mere acceptance of a member from a particular group would impair its message. But here Dale, by his own admission, is one of a group of gay Scouts who have "become leaders in their community and are open and honest about their sexual orientation." ... Dale was the copresident of a gay and lesbian organisation at college and remains a gay rights activist. Dale's presence in the Boy Scouts would, at the very least, force the organisation to send a message, both to the youth members and the world, that the Boy Scouts accepts homosexual conduct as a legitimate form of behaviour ${ }^{41}$.

The Court's reasoning on the first amendment issues involved is worth quoting in full:

The New Jersey Supreme Court determined that the Boy Scouts' ability to disseminate its message was not significantly affected by the forced inclusion of Dale as an assistant scoutmaster because of the following findings:

"Boy Scout members do not associate for the purpose of disseminating the belief that homosexuality is immoral; Boy Scouts discourages its leaders from disseminating any views on sexual issues; and Boy Scouts includes sponsors and members who subscribe to different views in respect of homosexuality." 160 N.J., at 612, 734 A.2d, at 1223.

We disagree with the New Jersey Supreme Court's conclusion drawn from these findings.

41 Boy Scouts of America v. Dale, 120 S.Ct. at 2451, 2453-54. 
First, associations do not have to associate for the "purpose" of disseminating a certain message in order to be entitled to the protections of the First Amendment. An association must merely engage in expressive activity that could be impaired in order to be entitled to protection....

Second, even if the Boy Scouts discourages Scout leaders from disseminating views on sexual issues -a fact that the Boy Scouts disputes with contrary evidence- the First Amendment protects the Boy Scouts' method of expression. If the Boy Scouts wishes Scout leaders to avoid questions of sexuality and teach only by example, this fact does not negate the sincerity of its belief discussed above.

Third, the First Amendment simply does not require that every member of a group agree on every issue in order for the group's policy to be "expressive association." The Boy Scouts takes an official position with respect to homosexual conduct, and that is sufficient for First Amendment purposes. In this same vein, Dale makes much of the claim that the Boy Scouts does not revoke the membership of heterosexual Scout leaders that openly disagree with the Boy Scouts' policy on sexual orientation. But if this is true, it is irrelevant. The presence of an avowed homosexual and gay rights activist in an assistant scoutmaster's uniform sends a distinctly different message from the presence of a heterosexual assistant scoutmaster who is on record as disagreeing with Boy Scouts policy. The Boy Scouts has a First Amendment right to choose to send one message but not the other. The fact that the organisation does not trumpet its views from the housetops, or that it tolerates dissent within its ranks, does not mean that its views receive no First Amendment protection.

Having determined that the Boy Scouts is an expressive association and that the forced inclusion of Dale would significantly affect its expression, we inquire whether the application of New Jersey's public accommodations law to require that the Boy Scouts accept Dale as an assistant scoutmaster runs afoul of the Scouts' freedom of expressive association. We conclude that it does.

The Court then turned its attention to the ever-increasing scope of State non-discrimination laws.

State public accommodations laws were originally enacted to prevent discrimination in traditional places of public accommodation, like inns and trains. ...In this case, the New Jersey Supreme Court went a step further and applied its public accommodations law to a private entity without even attempting to tie the term "place" to a physical location. As the definition of "public accommodation" has expanded from clearly commercial entities, such as restaurants, bars, and hotels, to membership organisations such as the Boy Scouts, the potential for conflict between state public accommodations laws and the First Amendment rights of organisations has increased. ... We have already concluded that a state requirement that the Boy Scouts retain Dale as an assistant scoutmaster would significantly burden the organisation's right to oppose or disfavour homosexual conduct. The state 
interests embodied in New Jersey's public accommodations law do not justify such a severe intrusion on the Boy Scouts' rights to freedom of expressive association. That being the case, we hold that the First Amendment prohibits the State from imposing such a requirement through the application of its public accommodations law ${ }^{42}$.

Speaking for the four dissenters, Justice John Paul Stevens wrote:

The majority holds that New Jersey's law violates BSA's right to associate and its right to free speech. But that law does not "impos[e] any serious burdens" on BSA's "collective effort on behalf of [its] shared goals," ... nor does it force BSA to communicate any message that it does not wish to endorse. New Jersey's law, therefore, abridges no constitutional right of the Boy Scouts ${ }^{43}$.

The relevance of Dale to churches and religious institutions was clear at the outset. New Jersey's definition of "public accommodation" is broad enough to include not only organisations having a religious character, but also churches themselves. If the state has a "compelling state interest" in eradicating discrimination, and may do so by forcing an organisation to admit, or employ, an individual whose expression, lifestyle, or conduct conveys a message antithetical to that of the organisation, the right of individuals to form groups for the collective expression and furtherance of their beliefs is subject to significant government oversight. It will no longer be possible to assume that there a "religious exemption" is available when the state feels that other important interests are at stake.

This is no small issue. The four dissenting Justices make it clear that only "serious" burdens on an organisation's "collective effort on behalf of [its] shared goals" will rise to the level of a constitutional violation. In the dissenters' view, the Court

... must inquire whether the group is, in fact, expressing a message (whatever it may be) and whether that message (if one is expressed) is significantly affected by a State's anti-discrimination law. More critically, that inquiry requires our independent analysis, rather than deference to a group's litigating posture. Reflection on the subject dictates that such an inquiry is required.

... To prevail in asserting a right of expressive association as a defence to a charge of violating an anti-discrimination law, the organisation must at least show it has adopted and advocated an unequivocal position inconsistent with a position advocated or epitomised by the person whom the organisation seeks to exclude. If this Court were to defer to whatever position an

42 Dale, 120 S.Ct. at 2455-56 (footnotes omitted).

43 Dale, 120 S.Ct. at 2459-60 (Stevens, Breyer, Souter \& Ginsburg, JJ., dissenting). 
organisation is prepared to assert in its briefs, there would be no way to mark the proper boundary between genuine exercises of the right to associate, on the one hand, and sham claims that are simply attempts to insulate non-expressive private discrimination, on the other hand. Shielding a litigant's claim from judicial scrutiny would, in turn, render civil rights legislation a nullity, and turn this important constitutional right into a farce. Accordingly, the Court's prescription of total deference will not do ${ }^{44}$.

The decision in Dale is thus enormously important from a legal and constitutional perspective. By a one-vote margin, the Court holds that an organisation need not justify either the content or pedigree of its ideological, political, or religious viewpoints to the state, nor may it be forced to prove that they are "unequivocally inconsistent" with the position "advanced or epitomised by the person whom the organisation seeks to exclude." But lawyers need to pay close attention. Four votes exist for the proposition that civil rights claims require the organisation to justify not only the content of its beliefs, but also its pedigree, internal consistency, and importance to its overall belief system. Dale thus sits squarely in a poorly understood, and often ignored, line of religious liberty cases: i.e. those that deal with judicial attempts to intervene in internal church controversies ${ }^{45}$.

Dale also has enormous political significance in the 2000 elections. That summary will be presented in Part II.

\section{THE POLITICAL RELEVANCE OF CONSTITUTIONAL DECISION-MAKING: PRESIDENTIAL POLITICS AND THE MEMBERSHIP OF THE SUPREME COURT}

Consider now the upcoming presidential, congressional, and state elections. On November 2, 2000, American will select a President who will likely have the opportunity to appoint at least two members of the Supreme Court during his first four-year term in office. Political lines are sharply drawn across the country on a wide variety of issues relevant in the religious liberty context. Among them are contentious issues like:

- "School choice" (i.e. government assistance for children attending religious and other non-public schools). Government funded alternatives to public schools is one of the hottest issues in the ongoing

44120 S.Ct. at 2454 (Stevens, Breyer, Souter \& Ginsburg, JJ., dissenting).

45 See, e.g. Serbian Eastern Orthodox Diocese for the United States of America and Canada v. Milivojevich, 426 U.S. 696 (1976). 
political campaign. In many minority communities in the United States there is strong support for breaking the public school monopoly on public school financing. The composition of the Court will determine what types of aid are permitted, and the constitutional analysis required in such cases. Were $\mathrm{Al}$ Gore to win, the scope of permitted governmental assistance will likely be narrowed, and the standards for granting it tightened. Were George W. Bush to win, the scope of assistance will likely be broadened, and the analysis harmonised with that applicable in other civil rights cases. This would have the effect of narrowing the States' ability to deny educational assistance on state constitutional grounds.

- "Charitable Choice": Both Texas Governor George W. Bush and Vice-President Al Gore are publicly committed to the support of "Charitable Choice" - a program whereby government agencies contract with religious organisations, including churches, for the delivery of a wide variety of social service programs (e.g., job training, drug treatment, day-care, etc.). The decision in Mitchell v. Helms deals with one of the most contentious issues in this debate: the steps that must be taken to assure that aid is not "diverted" to religious uses. The other, even more contentious issue is the impact of non-discrimination laws. Religious groups are free to discriminate on the basis of religion under controlling federal employment law. "Charitable Choice" opponents are concerned that the freedom to define the content of social welfare programs will be utilised as a license to discriminate on the basis of ideological and religious viewpoint, thus excluding members of minority religious groups from employment in the government funded social service sector. Dale speaks to this issue as well, particularly insofar as it requires groups like the Boy Scouts (and, by implication, churches) to be clear and overt about their teachings, the nature of their employment and membership policies, and the "connection" between their ideological views and the organisation's mission and purpose.

- Abortion: Though not directly relevant to this analysis, the Court is deeply divided over the issue of abortion. Its most recent decision on the subject, Stenberg v. Catbart, invalidated a Nebraska law prohibiting "partial birth abortions," a practice that entails partial delivery of a late-term unborn child, the vacuum suctioning of its brain, and finally, extraction from the womb. The Court split 5-4 on this issue. Its relevance here is twofold. First, the decision rests on a standard of review known as "undue burden". In this view, a statute restricting 
abortion is unconstitutional if it imposes an "undue burden" on a woman's right to choose to terminate a pregnancy. In Dale, by contrast, the same Justices who view a "substantial burden" inquiry as too rigorous in an abortion context reject the same inquiry as applied to an organisation's right to expressive association. The same holds true for the rights of anti-abortion protesters. Any other subject gets "strong" protection under the first amendment, but where, as in Hill v. Colorado, the Court believes that the exercise of first amendment rights my impose an undue burden on the fundamental rights of others, the standard of review is more lenient.

- Balancing non-discrimination concerns against freedom of expression: Both Boy Scouts of America v. Dale and Hill v. Colorado involve a question of balancing. Generally speaking, the United States Supreme Court takes a very protective stance whenever government seeks to control speech on the basis of its content or viewpoint. In recent years, however, the lower courts, both state and federal, have been dealing with claims that private or public speech alone might constitute a violation of the civil rights laws. The decisions in Dale and Hill v. Colorado make it clear that the scope of protection for freedom of speech and religion may depend in anti-discrimination cases on the Court's willingness to accept the content or viewpoint expressed.

What does this admittedly cursory (and somewhat opinionated) analysis tell most Americans? The short answer is that the 2000 election is not only about the shape of specific policy proposals generated and debated by the Presidential candidates and those running for Congress, the Senate and similar offices in the states, but also that the direction of the Supreme Court for the next generation hangs in the balance. There are indications that the public is aware that this is the case, but it is too early (at this writing) to tell how significant an issue it will be in the November elections.

\section{CONCLUSION}

Much of the case law governing religious freedom in the United States is converging with its counterparts in the related areas of freedom of speech and press, association, and equality. It will take several years before the contours of that convergence are apparent, and several more before the full implications of this trend are integrated into the corpus 
of case law. But the trend is clear. It is no longer possible to view freedom of religion in isolation from the community in which it exists. How it should be "balanced" against the interests protected by other fundamental rights will be an issue of critical importance in the years to come.

The decisions of the 1999 October Term give us some sense for where the law is going, and what the issues of the future will look like. Though it is too early to tell what conclusions will ultimately be drawn from the Constitution, it is very clear that the power entrusted to judges to determine the meaning of the law is a political judgement of the highest order. Politicians know it and judges know it. The interesting question during this election cycle is whether the voters will give this issue the important place in the national debate that it deserves. 